\title{
ARMLESS FIGURES IN ANCIENT EGYPT UNTIL THE END OF THE NEW KINGDOM
}

\author{
Mona Abou El Maati EL NADI
}

Cairo University- Faculty of Archaeology

Email: Dr.monaelnadi@ymail.com

\begin{abstract}
Figures with physical disabilities were rarely represented in ancient Egyptian art. The idealistic representation of the body was the customary rule followed by gods and kings. Predynastic and Dynastic exceptions suggest the intention to display disability by representing figures with bodies but without their arms. It is argued that the armless figures must have played a significant role, especially during funerary rituals. Predynastic examples discussed here include figures without arms related to funerary rituals, accompanying the funerary boats or deposited inside tombs to bless the deceased. Dynastic examples raise the possibility that these armless figures were divine and may have played a dedicated role in the deceased's funerary fate. A lack of arms may have represented the state of disability itself. The armless figures may have imitated the sun god's period of weakness during his journey through the night, perhaps playing a role that was suspended for a while, and continued in the afterlife. Their role may have been as guardians of the burial place or demons protecting the deceased. Some divine figures appear with a definite role to help the sun god in his night hours journey, as in the Amduat.
\end{abstract}

\section{KEYWORDS}

armless, disability, decorum, Neper, stump arms, Predynastic, paralysed arms, hidden arms, netherworld

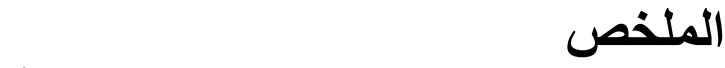

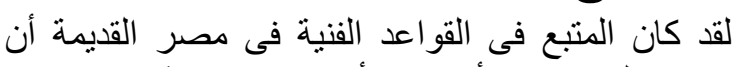

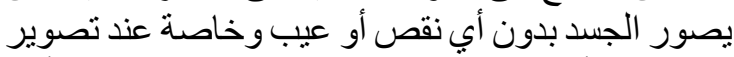

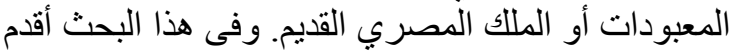

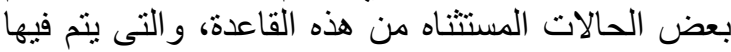

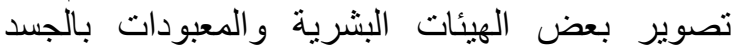

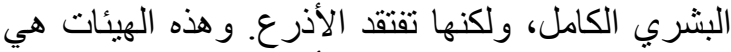

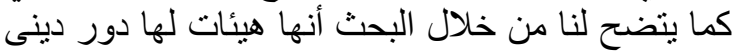

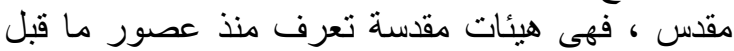

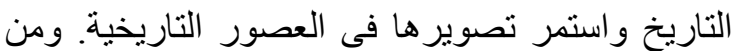

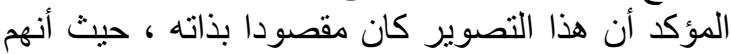

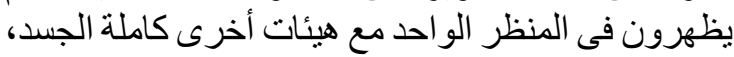

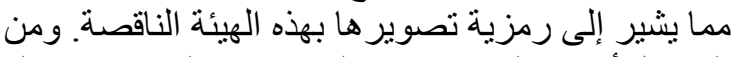

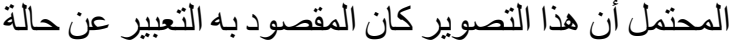

$$
\begin{aligned}
& \text { من الضعف، وتوقف الدور والوظيفة لهذه الهيئة ل لمدة }
\end{aligned}
$$

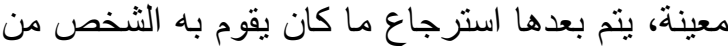

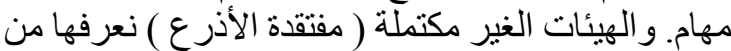

$$
\begin{aligned}
& \text { عصور ما قبل الأسرات، وقد قدمت بعض الآن الآر اء بالنسبة }
\end{aligned}
$$

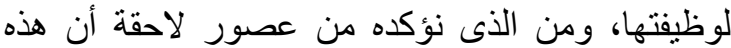

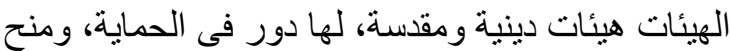

$$
\begin{aligned}
& \text { البركة للمتوفى. وقد ارتبطت بالطقوس الدينية المرتبطة }
\end{aligned}
$$

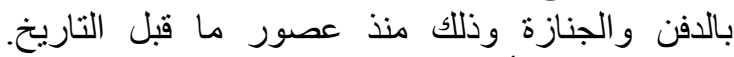

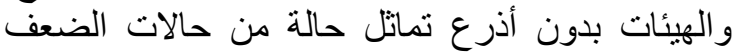

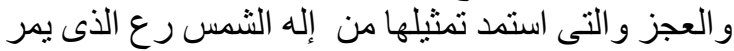

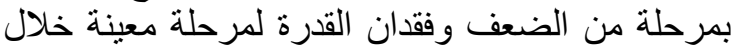

$$
\begin{aligned}
& \text { ساعات الليل ليستعيد بعد فترة قوته وحيو لفيته. } \\
& \text { الكلمات الدالة الكات لئل }
\end{aligned}
$$

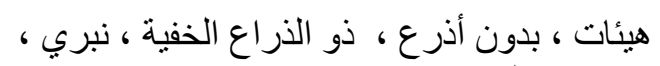

$$
\begin{aligned}
& \text { مر اكب ، الدفن ، الإيمى دوات دات التراع }
\end{aligned}
$$

\section{INTRODUCTION}

In ancient Egypt, religious anthropomorphic representations carried a message created by the artist that the audience could interpreted, even as early as the Predynastic Period. ${ }^{1}$ This art

${ }^{1}$ Hendrickx, S., 'Iconography of the Predynastic and Early Dynastic Periods', In Emily Teeter (ed.) Before the Pyramids: The Origins of Egyptian Civilization, OIP 33, Chicago, (2011), 75-76, 81. 
had to adopt and follow specific rules, especially that it most likely was created to serve practical purposes. ${ }^{1}$ Among those rules was the representation of the body's idealistic shape for both gods and kings. The artists rarely showed their kings or divine creatures with actual disabilities or deformities. ${ }^{2}$ However, this paper presents exceptions to this Egyptian cultural standard in depicting some divine figures in a full human body, but without representing the arms or intentionally 'armless'.

The objectives of the research are to identify and analyse the armless figures from Predynastic Egypt to the end of the New Kingdom, as well as interpret them to explain their symbolic functions and meanings.

First, the figures considered in this study are specifically those represented with a full human body, yet without arms, ${ }^{3}$ rather than those whose arms are hidden under cloaks, such as those inside a shrine on Early Dynastic ivory tablets, mace-heads or tusk figurines. ${ }^{4}$ It has been suggested that they could be predecessors of mummies representing the earliest gods. ${ }^{5}$ The focus here lies in human representations showing enough details, even in an abbreviated style, but with no arms. During the prehistoric times, stumps were in many cases provided as a replacement [Fig.1]. As the presented evidence proves, they were intentionally represented in this condition. As a result, this article suggests that they must have had their own purpose, symbolic, function and meaning, distinct from representations of armed humans.

A recent study identified human figures with stumps instead of arms as the most numerous, hence the worthiest of research, during the Predynastic Period rather than those with raised arms. while relating between the former and armless figures with triangular bodies painted on Predynastic pottery. ${ }^{6}$ The study argued that stumps replacing arms must have served a stylistic function, rather than a practical one to avoid breakage. However, this study was only based on a collection of Naqada II figures discovered by De Morgan in El-Ma'mariya. ${ }^{7}$ A recent study by the same author also included anthropomorphic objects, except for representations and covering only the Predynastic Period. ${ }^{8}$ More examples are known from later periods. ${ }^{9}$

\footnotetext{
${ }^{1}$ Baines, J., 'On the Status and Purpose of Ancient Egyptian Art,' CAJ 4.1, (1994), 67-94,88; Gaballa, G.A., Narrative in Egyptian Art Philipp von Zabern, Mainz am Rhein (1976), 77.

${ }^{2}$ Smith, W.S., A History of Egyptian Sculpture and Paintings, Sculpture and Paintings in the Old Kingdom, 2nd ed., Boston, (1949); Robins, G., Proportion Style in Ancient Egyptian Art, Texas, (1994); Weeks, K.R., The Anatomical Knowledge of Ancient Egyptians and the Representation of Human Figure in Egyptian Art, PhD diss., Yale University, (1970); Kanawati, N\& Woods, A., Artists in the Old Kingdom; Techniques and Achievements, Cairo, (2009).

${ }^{3}$ The goddess Rpwt is a goddess known from the Old Kingdom. She is shown as a woman. Her name is written

with the determinative of an armless woman inside a shrine as

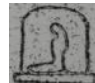

3. Kaiser, W. “Zu den ₹ 秝 der Alteren Bilddarstellungen und der Bedeutung von rpwt, in: MDAIK 39 (1983), 274-296; WB II,415,1.

${ }^{4}$ See for example: The mace-head of King Narmer or The label of King Djer.

${ }^{5}$ Demarée, R.J., The 3h ikr $n$ R Stelae, On Ancestor Worship in Ancient Egypt, (1983); Harrington N., Living with the Dead, Ancestor Worship and Mortuary Ritual in Ancient Egypt, (2013).

${ }^{6}$ Ordynat, R., The Female Form: Examining the Function of Predynastic Female Figurines from the Badarian to the Late Naqada II Periods, BA Thesis, Monash University, Australia, (2013)., 1-19, especially 12-13.

${ }^{7}$ The collection is currently at the Brooklyn Museum, New York.

${ }^{8}$ Ordynat, R., Egyptian Predynastic Anthropomorphic Objects, 57ff.

${ }^{9}$ El-Yahky, F., Remarks on the Armless Human Figures Represented on Gerzean Boats', in JSSEA XI-No.2 (1981), $77 \mathrm{ff}$.
} 


\section{REPRESENTATION OF ARMLESS FIGURES IN ANCIENT EGYPTIAN ART}

First appearances of armless human figures date to Predynastic times, ${ }^{1}$ despite human figurines being rare. The better-known examples come from Upper Egypt. ${ }^{2}$ Dating to the Badarian (ca. 4500-4000 BC) and Naqada I-II (ca. 4000-3600 BC) Periods, women figurines [Fig.1] are executed in the abbreviated style, with a beak-like head and stumps as arms. Their steatopygia makes them comparable to Prehistoric Venus figurines. ${ }^{3}$ This type of armless female figurines is known as "serving figures", made of pottery. When they exhibit stumped arms, they have a flat, hollowed head. ${ }^{4}$ Realistic figures are found alongside abbreviated ones, demonstrating the artist's capability to create both, and confirming that the latter examples were deliberately styled in that fashion. ${ }^{5}$

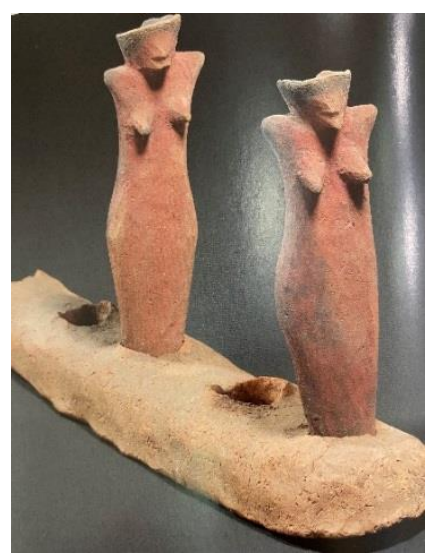

Figure 1: Female serving figures, Late Naqada I-early Naqada II [after D.C. Patch, Dawn of Egyptian Art, Cat.95,96].

Female figurines, including those with exaggerated features, increased in number during the early Predynastic Period. ${ }^{6}$ A few crude examples are made of unbaked clay and show stumps instead of arms. ${ }^{7} \mathrm{~A}$ female figurine also made of clay is seated inside a model boat

\footnotetext{
${ }^{1}$ Petrie, W.M.F., Prehistoric Egypt, London, (1920); Brunton, G.and Caton-Thompson, G., 'The Badarian Civilization and Predynastic Remains near Badari', BSAE 46, London, (1928), 28ff; Smith, W., A History of Egyptian Sculpture and painting, London, (1946).

${ }^{2}$ Patch, D.C(ed.), Dawn of Egyptian Art, Metropolitan Museum of Art, New York, (2012), 100.

${ }^{3}$ Hornblower, G.D., "Predynastic Women and their Successors, and their Successors", in: JEA 15 (1929), 2947; Wunn, I\& Grojnowski, D., The Origin of Religion in the Evolution of Humans, in Ina Wunn and Davina Grojnowski (eds.), Religious Speciation: How Religions Evolve, New Approaches to the Scientific Study of Religion, NASR 6 (2019), 223-241. Mother figurines, such as the Willendorf Venus, or other nude female figures, were known in Europe since the Upper Paleolithic, usually represented with hardly any features, emphasizing their femininity. The arms are almost always missing with these abstract features and only hold the breasts or point to the thighs or belly when represented. Their function was associated with fertility, although it is now clear that it changed when Prehistoric society changed its subsistence from hunting to agriculture. The absence of arms can be contrasted to the exaggeration of the female aspects, which is explained by the fertility function not requiring the use of arms.

${ }^{4}$ Petrie,W.M.F. \& Mace A.C., Diospolis Parva, London (1901), 33; Patch, Dawn of Egyptian Art, 117.

${ }^{5}$ Patch, Dawn of Egyptian Art, 103.

${ }^{6}$ Patch, Dawn of Egyptian Art,110.

${ }^{7}$ Patch, Dawn of Egyptian Art, fig. 33.
} 
underneath a mat shield. ${ }^{1}$ It does not have arms and also lacks the stumps protruding from the shoulders [Fig. 2].

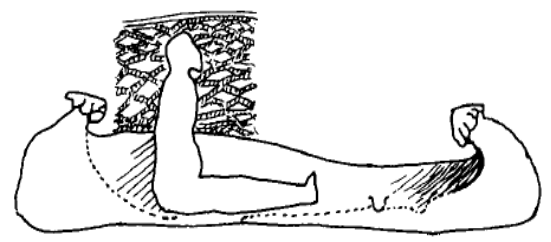

Figure 2: An Armless Female Figure Seated inside a Boat Model [after El-Yahky, Gerzian Boats, pl. XXXIII.2].

Stick or reed armless figurines are known from the early Naqada Period. They continue being produced as both males and females with stumps replacing the arms in an abbreviated style. ${ }^{2}$ Decorated pottery dating to Naqada II Period shows female figurines with stump arms painted on the exterior surface. As seen in [Fig.3], ${ }^{3}$ the human figure is a female based on body characteristics.
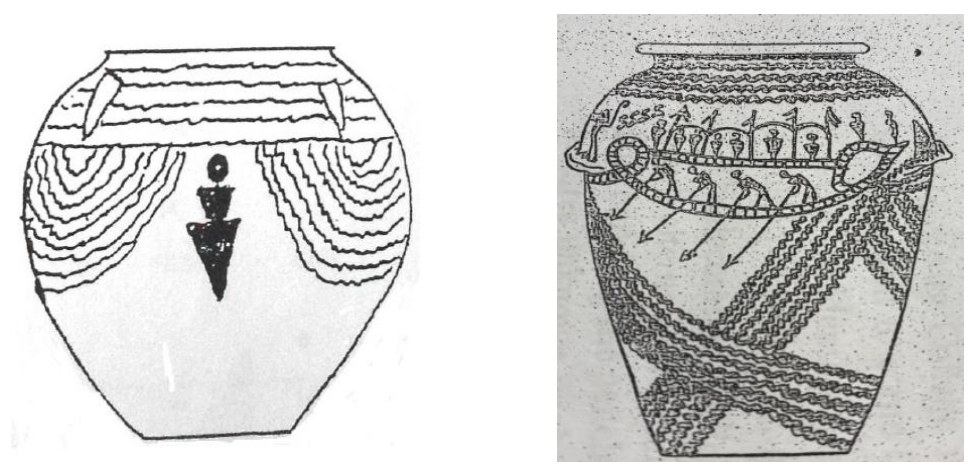

Figure 3 [Left]: Representation of a Human Figure with Stump Arms on a Naqada II Pot [after Relke, Predynastic Figurine, 63$]^{4}$

Figure 4 [Right]: A Naqada II Pot with Wavy Handles showing Armless Figures in boat cabins [after Payne J.C., JEA 63, fig.4].

Painted pottery was used to display wealth, and boat scenes were a common theme. Armless figures are associated with funerary boats, seen as symbolising the dead's soul or 'order out of chaos' and power over it, ${ }^{5}$ among other interpretations including representing the afterlife. ${ }^{6}$ In [Fig.4], ${ }^{7}$ armless females are seen inside the cabins of a large boat, while sailors

\footnotetext{
${ }^{1}$ Petrie, W.M.F., Prehistoric Egypt.; El-Yahky, F., "Clarifications on the Gerzean Boat Scenes", in: BIFAO 85, 1985, 187-195, Pl. XXXIII.2.

${ }^{2}$ Patch, D.C., Dawn of Egyptian Art, 118 (Cat.98).

${ }^{3}$ For more examples from late Naqada II to Naqada III see: El-Yahky, "Clarifications on the Gerzean Boat Scenes", pl. XXXIV.

${ }^{4}$ Relke, J., The Predynastic Figurines of Upper Egypt, PhD Thesis, (2001), 63; Ordynat, Female Form, 11, fig. 4.

${ }^{5}$ Vanhulle, D., Boat Symbolism in Predynastic and Early Dynastic Egypt: An Ethno-Archaeological Approach. JAEIN 17, (2018),173; Hendrickx and Eyckerman, "Iconography of the Predynastic and Early Dynastic Periods", 121-144.

${ }^{6}$ Graff, G., Les peintures sur vases de Nagada I - Nagada II: Nouvelle approche sémiologique de l'iconographie prédynastique, Leuven University Press, (2009), 121-124.

7 The authenticity of decorations on a late Naqada II period - or or possibly early Naqada III - pot with wavy handles [Fig.4] cannot be confirmed. Hence, caution needs to be practiced when dealing with what is being
} 
are holding the oars to direct the ship. These armless females may represent the dead relatives of the deceased, giving their blessing. ${ }^{1}$ Indeed, this representation shows that the potter could execute humans with a full body, and others without.

During the dynastic periods, figures intentionally lacking arms were rare. Examples from the New Kingdom (1570 BC-1544BC) represent armless figures in some individuals' tombs.

\section{Four indefinite armless figures in funerary rituals}

Four indefinite armless figures appear in a funerary ritual scene; these appear to be intentionally without arms. A rectangular shrine framed by a frieze of kheker ornaments ${ }^{2}$ encloses four male figures, with no arms, facing two by two. They have short hair and wear short kilts. Their bodies and clothes are alternately yellow (colour of the sun), and blue (colour of the night). The four armless figures appear - with no differences in depictions in several tombs from Thebes. ${ }^{3}$ They differ in their appearance and position relative to the shrine of the god Osiris, ${ }^{4}$ as presented in the following table.

Different activities were performed during the pilgrimage to the sacred places, or during the funeral of a deceased, as the burial scenes of a deceased were prevalent. The whole scene displays completely a series - often compact of micro-scenes in no particular order.

\section{Table 1:}

\begin{tabular}{|c|c|c|c|}
\hline Tomb No. & Ref. & Plate & Comment \\
\hline $\begin{array}{l}\text { Tetiky (TT 15) } \\
17^{\text {th }} \text { Dyn., Ahmose } \\
\text { I }\end{array}$ & $\begin{array}{l}\text { PM I, p.26-27; } \\
\text { Settgast, ADAIK } \\
3,52 \mathrm{ff} \text {. }\end{array}$ & 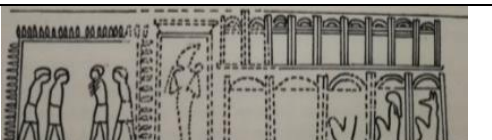 & $\begin{array}{l}\text { In front of the shrine } \\
\text { of Osiris. }\end{array}$ \\
\hline $\begin{array}{l}\text { Ineni (TT 81) } \\
18^{\text {th }} \text { Dyn., } \\
\text { Amenhotep I }\end{array}$ & PM I, 159. & 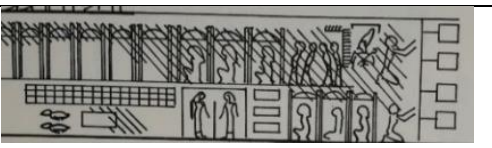 & $\begin{array}{l}\text { Beside the shrine of } \\
\text { Osiris }\end{array}$ \\
\hline $\begin{array}{l}\text { User (TT 21) } \\
18^{\text {th }} \text { Dyn., } \\
\text { Thutmosis I }\end{array}$ & PM I, 35. & 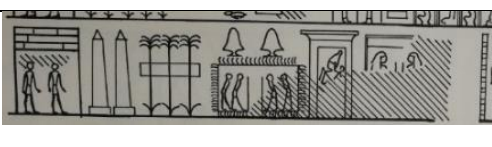 & $\begin{array}{l}\text { In front of the shrine } \\
\text { of Osiris }\end{array}$ \\
\hline
\end{tabular}

shown, See: Petrie, W.M.F., Ancient Egypt, Part I, British School of Archaeology, (1914-1917), 43, fig. 29; Payne J.C., "Forged Decoration on Predynastic Pots", in: JEA 63, London, (1977), 5-12; Graff, Les peintures sur vases de Nagada I - Nagada II ,14.

${ }^{1}$ Petrie, Ancient Egypt, 43.

${ }^{2} \mathrm{~A}$ decorative motif commonly employed in ancient Egyptian architecture from at least as early as the $3^{\text {rd }}$ Dynasty. It is usually found on the tops of high outer walls. It is also an ornament for the cornice of roofed chambers. Wb III, 401; Gardiner, A., Egyptian Grammar Being an Introduction to the Study of Hieroglyphs, Oxford, (1957) 543; Petrie, W.M.F., Egyptian Decorative Art, London, (1895), 101-103; Shaw, I. \& Nicholson, P., The British Museum Dictionary of Ancient Egypt, Cairo, (2002), 150; Ćwiek, A., 'Relief Decoration in the Royal Funerary Complexes of the Old Kingdom, Studies in the development, Scene Content and Iconography', Warsaw University, (2003), fig.48; Fathy, N., 'Hkr (Kheker) Frieze in Ancient Egypt', JGUAA 2, (2017), 132158; Stevens, C.J., "The Oxford Dictionary of Architecture, (2016); Badawy, A., A History of Egyptian Architecture, vol.I-III, (1955-1968).

${ }^{3}$ Settgast, J. "Untersuchungen zu Altägyptischen Bestattungsdarstellungen”, in: ADAIK 3, New York 1963p.52ff.

${ }^{4}$ Davies N.de G., The Tomb of Antefoker of Sesostris I and of his wife Senet (no.60), (1920). 


\begin{tabular}{|c|c|c|c|}
\hline $\begin{array}{l}\text { Rekhmire (TT } \\
\text { 100) } 18^{\text {th }} \text { Dyn. }{ }^{1} \text {, } \\
\text { Thutmosis III \& } \\
\text { Amenhotep II }\end{array}$ & $\begin{array}{l}\text { N.de G. Davies, } \\
\text { The Tomb of } \\
\text { Rekhmire at } \\
\text { Thebes, pl. } \\
\text { LXXXVII }\end{array}$ & 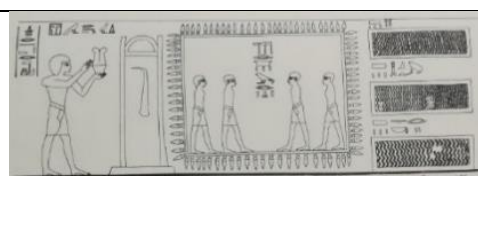 & $\begin{array}{l}\text { Far from the shrine of } \\
\text { Osiris. A text is written } \\
\text { referring to their role. }\end{array}$ \\
\hline $\begin{array}{l}\text { Puyemre (TT } \\
\text { 39) } \\
18^{\text {th }} \text { Dyn., } \\
\text { Thutmosis III }\end{array}$ & $\begin{array}{l}\text { PM I, p.71; N.de } \\
\text { G. Davies, The } \\
\text { Tomb of Puyemre, } \\
\text { pl.XLVII. }\end{array}$ & & $\begin{array}{l}\text { Beside the shrine of } \\
\text { the three female } \\
\text { mourners }{ }^{3}\end{array}$ \\
\hline $\begin{array}{l}\text { Paheri (EK-3) } \\
18^{\text {th }} \text { Dyn., } \\
\text { Thutmosis III }\end{array}$ & $\begin{array}{l}\text { T. Griffith, The } \\
\text { Tomb of Paheri, } \\
\text { pl.5; L. Manniche, } \\
\text { Lost Tombs, } 75 \text {, } \\
\text { pl.28. }\end{array}$ & & $\begin{array}{l}\text { Behind the shrine of } \\
\text { Osiris. }\end{array}$ \\
\hline $\begin{array}{l}\text { Siuser (A4) } \\
18^{\text {th }} \text { Dyn. }\end{array}$ & $\begin{array}{l}\text { PM I, p.447; L. } \\
\text { Manniche, Lost } \\
\text { Tombs, pl.28. }\end{array}$ & 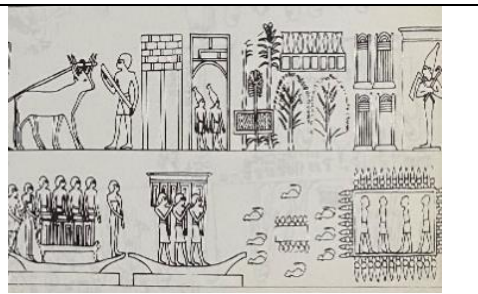 & $\begin{array}{l}\text { The shrine exists in the } \\
\text { final act of the funerary } \\
\text { rituals. The shrine of } \\
\text { Osiris appears in the } \\
\text { upper register. Four } \\
\text { men guards the coffin. }\end{array}$ \\
\hline $\begin{array}{l}\text { Amenemhat (TT } \\
\text { 53) } \\
18^{\text {th }} \text { Dyn., } \\
\text { Thutmosis III }\end{array}$ & $\begin{array}{l}\text { Settgast, J. } \\
\text { Untersuchungen } \\
\text { zu } \\
\text { Altägyptischen } \\
\text { Bestattungsdarst } \\
\text { ellungen, in } \\
\text { ADAIK } 3, \text { New } \\
\text { York } 1963,54 \text {. }\end{array}$ & 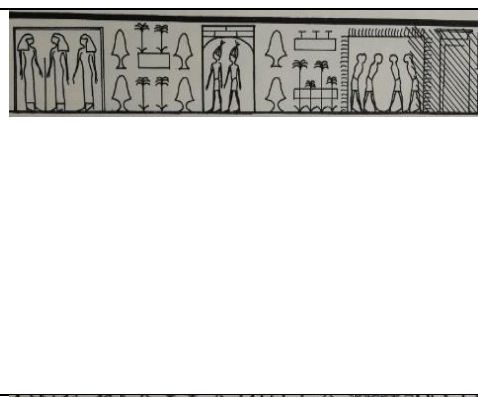 & $\begin{array}{l}\text { Beside the shrine of } \\
\text { Osiris. }\end{array}$ \\
\hline $\begin{array}{l}\text { Amenemhat (TT } \\
\text { 123) } \\
18^{\text {th }} \text { Dyn., } \\
\text { Thutmosis III }\end{array}$ & PM I, 236. & RMAR & $\begin{array}{l}\text { Behind the shrine of } \\
\text { Osiris. }\end{array}$ \\
\hline
\end{tabular}

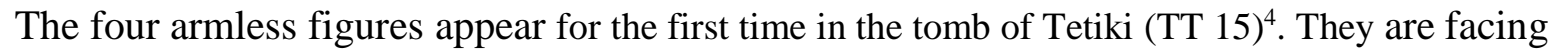
each other, two by two, with short kilts. The colours of their kilts and their bodies are apparent in the tombs of Rekhmire and Paheri.

The existence of the Shrine of the four armless figures near that of Osiris in various tombs, as highlighted in the previous table, implies their involvement in the realm of the dead in the land of Osiris. Moreover, in a shrine, three female figures, perhaps goddesses, are expressing their sadness by the placement of their hands in front of their head. ${ }^{5}$

\footnotetext{
${ }^{1}$ Rekhmire was an $18^{\text {th }}$ Dynasty vizier and mayor of Thebes during the reigns of Thutmosis III and Amenhotep II. His tomb (TT 100) is located in the Sheikh Abd el Qurnah Necropolis on the West bank at Luxor. ${ }^{2}$ Puyemre is the Second prophet of Amun during the reign of Thutmosis III.

${ }^{3}$ Settgast, "Untersuchungen zu Altägyptischen Bestattungsdarstellungen", 50-51.

${ }^{4} \mathrm{He}$ was the mayor of Thebes during the reign of Ahmose I. Baikie, J., Egyptian Antiquities in the Nile Valley, 1932; PM I, The Theban Necropolis, 26-27.

${ }^{5}$ Settgast, "Untersuchungen zu Altägyptischen Bestattungsdarstellungen”, 51.
} 


\section{II-Armless figures in the Book of the afterlife Amduat ${ }^{1}$}

Two figures are armless in the Book of the afterlife Amduat: the god Neper in the second hour, and five minor deities in the eleventh hour.

\section{a-The armless god Neper in the second hour of the Amduat ${ }^{2}$}

The illustrated version of the Second hour shows the boat of the sun god Ra in the second register. The boat is shown during his night journey, preceded by four other boats. They are in the place called "Werns", in which the god Osiris gives the gifts of the land to the inhabitants. ${ }^{3}$ The name of the gods who are in this place is 'The Souls of the duat'. They are worshipping the great god, and they are guiding him on his way. Some of them bring him the prayers of those who are upon the earth. They also lead disembodied souls to the forms which belong to them. Others mark the annual seasons.

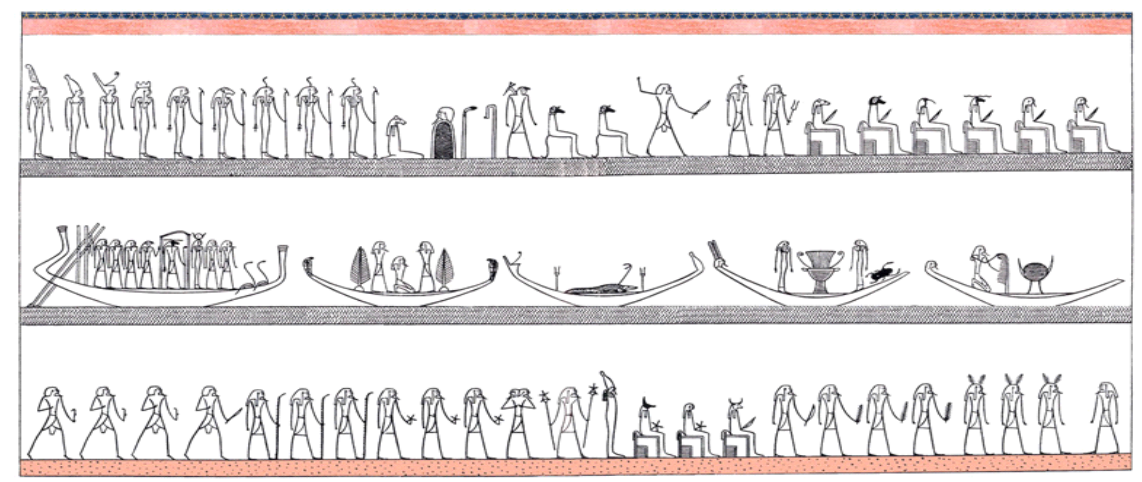

Figure 7: The Eleventh Hour of Amduat (after Hornung, Das Amduat, pl.217, 161).

In front of the boat of Ra, the first one shows the god Neper, the god of grain and of vegetation. Neper is considered an image of the god Osiris, the god of vegetation. ${ }^{4}$ The prow and stern of his boat terminate in cobra heads. There is a kneeling armless god in the centre of the boat, while two others are standing without arms. There are also two large wheat spikes.

\footnotetext{
${ }^{1}$ Hornung E., “Amduat” in: LÄ I, 184-187; Id., Die Unterweltsbücher der Ägypter, 69-74; Binder, S., 'The Hereafter: Ancient Egyptian Beliefs with Special Reference to the Amduat', BACE 6 (1995), 7ff; Hornung, E., The Ancient Egyptian Books of the Afterlife, London: Cornell University Press (1999), 43; Piankoff, A., The Tomb of Ramesses VI, NJ (Princeton University Press/Bollingen Series XL.1) (1954), 240ff.

${ }^{2}$ The Second Hour represents "The Field of Wernes" which is a fertile region due to its waterways. Here the sun god provides water and bread for the blessed.

${ }^{3}$ Piankoff, The Tomb of Ramesses VI, p.240.

${ }^{4}$ Leitz, Ch., LÄGG IV, 202; Abu-El-Nadar W., 'God Nepri in Ancient Egyptian Religion', in: EJARS 3.2,(2013), 107-114.
} 


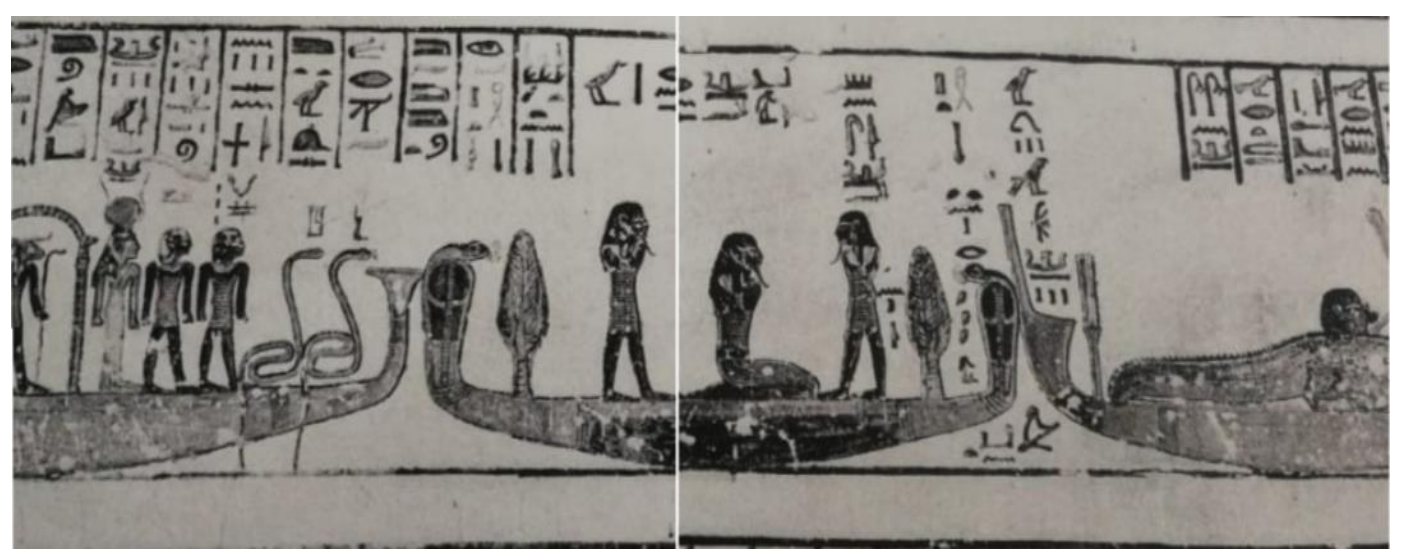

Figure 8: Detail of the Second Hour, Second Register.

The legend written by the ear of corn in the front of the boat reads: "The boat which conveys Neper". By the ear in the stern, one reads: "Collector of herbs and plants". The god Neper appears armless among two other unknown armless figures. The Elder books suggests that the one in the middle is a goddess. ${ }^{1}$ In contrast, the present author assumes that these three figures represent the god Neper, and the three seasons of the year (Inundation-Harvest-Sowing). Including the vegetal germination, growth and resurrection may guarantee a new birth for the sun god's boat. ${ }^{2}$

\section{b-The five armless minor deities in the eleventh hour}

The illustrated version of the eleventh hour shows "The place of rest of the inhabitants of the Netherworld". In the second register, the boat of the sun god is dragged by several gods. The upper register contains twelve minor deities. The first four are represented with a full human body, but the fifth to the tenth ones are armless, with their names in front of them.

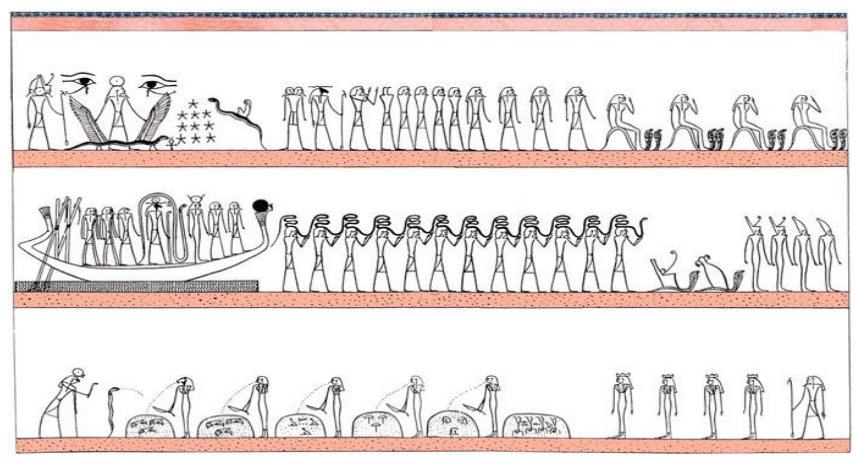

Figure 9: Eleventh hour of the Amduat (after E. Hornung, Die Unterweltsbücher der Ägypter, Abb.175).

\footnotetext{
${ }^{1}$ Hornung, E., The Egyptian Amduat, The Book of the Hidden chamber, Hardcover, (2007), 58. ${ }^{2}$ Hornung, Das Amduat, 202, Nr.161.
} 


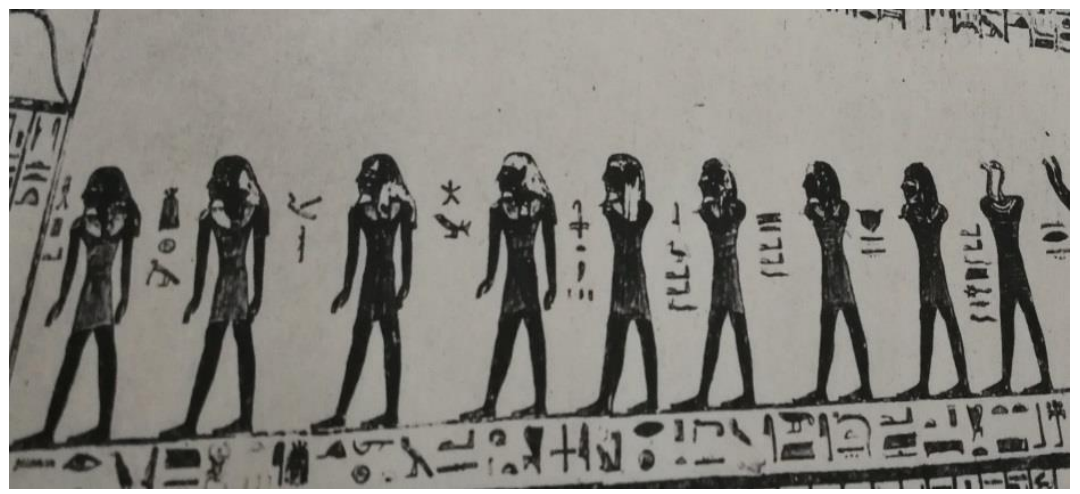

Figure 10: Detail of the upper register of the eleventh hour.

Table 2: Five Armless Minor Deities in the Amduat

\begin{tabular}{|c|c|c|}
\hline The deity & Meaning & Description \\
\hline $\begin{array}{l}\text { 1-The first deity is called } \\
\neq_{0} \therefore \text { oswt-iwf }\end{array}$ & "Flesh of the south"1 & $\begin{array}{l}\text { A full human minor deity } \\
\text { without arms }\end{array}$ \\
\hline $\begin{array}{l}\text { 2-The second deity is called } \\
\text { II }\end{array}$ & "His two arms are hidden"2 & $\begin{array}{l}\text { A full human minor deity } \\
\text { without arms }\end{array}$ \\
\hline $\begin{array}{l}\text { 3-The third deity is called } \\
\text { ( }\end{array}$ & $\begin{array}{l}\text { "The one with paralysed } \\
\text { arms"3 }\end{array}$ & $\begin{array}{l}\text {-A full human minor deity } \\
\text { without arms } \\
\text {-A designation of Khnum- } \\
\text { Ra in a ritual scene from the } \\
\text { Greco-Roman period }\end{array}$ \\
\hline $\begin{array}{l}\text { 4-The fourth deity is called } \\
\text { "wpwty t3.wy" }\end{array}$ & $\begin{array}{l}\text { "Separation of the two } \\
\text { lands"s }\end{array}$ & $\begin{array}{l}\text {-A full human minor deity } \\
\text { without arms }\end{array}$ \\
\hline $\begin{array}{l}\text { 5-The fifth deity is called } \\
\text { "s wy.fy } m \text { h } t . f "\end{array}$ & $\begin{array}{l}\text { "His two arms are in his } \\
\text { body"6 }\end{array}$ & $\begin{array}{l}\text {-A human deity with a } \\
\text { double snake head. } \\
\text { - Name of a sacred snake of } \\
\text { the } 13^{\text {th }} \text { Upper Egypt }\end{array}$ \\
\hline
\end{tabular}

\section{FUNCTIONS AND INTERPRETATIONS OF ARMLESS FIGURES}

Armless figures appear from the predynastic periods, but one must be cautious in interpreting their roles from such an early period. There were various artistic treatments of the human

\footnotetext{
${ }^{1}$ Leitz, “swt- iwf", in: $L \ddot{A} G G$ VI, 224.

${ }^{2} \mathrm{CT}$ III, $98 \mathrm{~m}$; dgg imn 'wy.fm $n \underline{\mathrm{t}} r$ "He whose hands are hidden will be seen as a god" A. de Buck, CT, spell 190; Leitz, "Imn-'wy.fy", in: $L \ddot{A} G G$ I, 342.

${ }^{3}$ Leitz, "Mr.n ${ }^{\varsigma} w y . f y "$, in: $L \ddot{A G G}$ III, 328.

${ }^{4}$ Esna VI, 510, 13.

${ }^{5}$ Leitz, "wpwty t3wy", in $L \ddot{A} G G$ II, 181. His name means that: "The one who separates between two domains" (earth/netherworld, pure/impure, sacred/profane), Lucarelli R., "The Guardian-Demons of the Book of the Dead", British Museum Studies in Ancient Egypt and Sudan 15, London, (2010), 85-102.

${ }^{6}$ Leitz, LÄGG II, 6; E I, 333, 14; Osing, J., Hieratische Papyri aus Tebtunis I, University of Copenhagen, (1998), y4, 11, S.184, Tf.15; II, L19, 29, S.244, Tf.25; designation of a serpent of the $13^{\text {th }}$ nome upper Egypt in the Greco-Roman period.

${ }^{7} \mathrm{~A}$ title that suits snakes as they have no legs or arms.
} 
body at this date, in different places and times. Nevertheless, the representation of a human without arms dated to that period evokes the hypothesis that these armless figures were associated with religious functions and roles. This is supported by the representations of armless individuals seen with funerary boats from the predynastic period to the dynastic periods. The armless figures must have had a role during the funeral, which was finished or suspended for a while and completed in the afterlife. The divine role of the armless figures is emphasised in funerary rituals of an early date.

During the New Kingdom, the four armless figures continue to appear with the funerary rituals and the burial. The place of the funeral is called " $t 3 d s r$ ", ${ }^{1}$ meaning "The holy ground". This term is traditionally translated as "The Necropolis". ${ }^{2}$ The four armless figures played the role of "guardians" during the funerary journey. ${ }^{3}$ The four figures are referred to by $n t r w$ $r 3 w w r w$ "Gods, keepers of the great gates" ${ }^{3}$ or "The gods at the great gates" in three tombs:

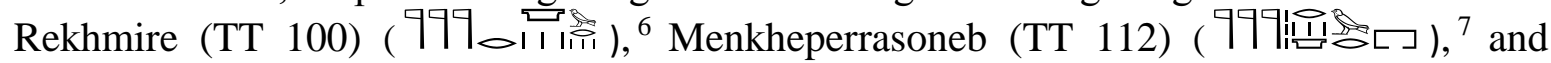
Hekamaetrenakht (TT 222) (

They are involved in different rituals performed in the cemetery. In ancient Egypt, several sacred places were visited by Egyptians to get a blessing from them. The most famous place was the district of Abydos, the city of the god Osiris, the god of the afterlife and the dead. The voyages to the sacred places were represented on tombs walls, ${ }^{9}$ even during the owner's life.

Other explanations of the role of the four armless figures are cited in the following table.

Table 3: Suggestions for the identity and role of the four armless figures

\begin{tabular}{|c|c|c|}
\hline Function & $\underline{t}$ teht & Comment \\
\hline 1- Guardians ${ }^{10}$ & 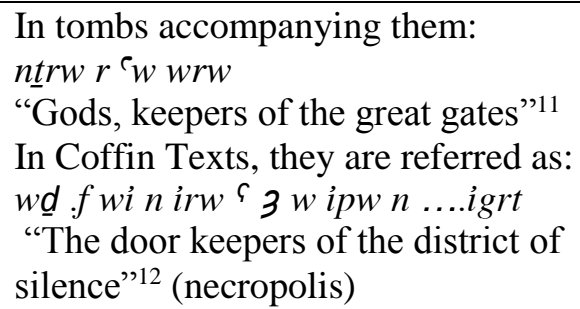 & $\begin{array}{l}\text { The difference in the colour of } \\
\text { the body of the four figures in } \\
\text { scenes, suggests that two of them } \\
\text { guarded the place during the } \\
\text { night (with blue colour), and the } \\
\text { two others during the day (in } \\
\text { yellow colour). }\end{array}$ \\
\hline $\begin{array}{l}\text { 2- Demons \& } \\
\text { Terrible Creatures }\end{array}$ & & $\begin{array}{l}\text { The lack of arms makes them } \\
\text { strange and scary. } .^{13}\end{array}$ \\
\hline
\end{tabular}

\footnotetext{
${ }^{1} \mathrm{~Wb} \mathrm{~V}, 228,6-9$.

${ }^{2}$ FCD, 293.

${ }^{3}$ Settgast, J., Untersuchungen zu Altägyptischen Bestattungsdarstellungen, 55; Diamond, K.A., Transporting the Deceased to Eternity: The Ancient Egyptian Term ḩ3i, BAR International Series 2179, (2010).

${ }^{4}$ Griffith, T., The Tomb of Paheri at el Kab, The Egypt Exploration Fund 11, London, (1894). 22, pl.V.

${ }^{5}$ Urk IV, 129,13; V, 67, 5.

${ }^{6}$ Davies, N.de G., The Tomb of Rekhmire at Thebes, PMMA XI, (1973), pl.LXXXVII.

${ }^{7}$ High priest of Amun (priest of Amun aashefyt)-Thutmosis III; PM I, 229; Davies, N.de G., The Tombs of

Menkheperrasonb, Amenmose, and Another, (Nos.86, 112, 42, 226), (1933).

${ }^{8} \mathrm{PM} \mathrm{I}, 323$; Settgast, Untersuchungen zu Altägyptischen Bestattungsdarstellungen, 52.

${ }^{9}$ Goyon, J.C., Rituels Funéraires de l'Ancienne Égypte, Paris, (1972).

${ }^{10}$ Davies, N.de G.,The Tomb of Puyemre at Thebes, vol.I-II, New York, (1923), 7, pl.XLVII.

${ }^{11}$ Griffith, T., The Tomb of Paheri, 22, pl. V; Urk IV, 129, 13; V, 67, 5.

${ }^{12} \mathrm{CT} \mathrm{V}, 333$ g-h.

${ }^{13}$ Davies N., Puyemre, 7; Guilhou, N., Génies Funéraires, 356-417; Lucarelli, R., The Guardian-Demons of the Book of the Dead, 85-102.
} 


\begin{tabular}{|c|c|c|}
\hline $\begin{array}{l}\text { 3-The Four sons of } \\
\text { Horus }\end{array}$ & 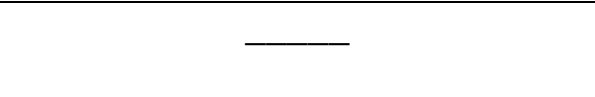 & $\begin{array}{l}\text { Later, they appear in funerary } \\
\text { rituals. } 1\end{array}$ \\
\hline 4-The Fighters & $\begin{array}{l}\text { Who conquer the enemies of Osiris } \\
\text { and lost their arms during the fight? } \\
\text { di.tw.n.f } 3 w y m \text { Nšmt hr w3wt imntt } \\
\text { "May he have arms in Neshmet in its } \\
\text { way on the western roads"2 }\end{array}$ & $\begin{array}{l}\text { In a story relating to a fight } \\
\text { against the enemies of Osiris, } \\
\text { some fighters lost their arms } \\
\text { during the struggle. It is written } \\
\text { on a stela from the Cairo } \\
\text { Museum (CG 20561). After, they } \\
\text { wish to have arms to defend } \\
\text { Osiris and restore him to life. The } \\
\text { armless fighters may have lost } \\
\text { their arms to prevent their } \\
\text { fighting. }{ }^{3} \text { This may be why their } \\
\text { shrines appear just behind Osiris. }\end{array}$ \\
\hline
\end{tabular}

The four armless figures were guardians of the place of burial and of the god Osiris. Whether demons, sons of Horus, or fighters of Osiris, their nature is more challenging to determine. Their number suggests other potential identities, such as the four $m w w$ dancers, ${ }^{4}$ the four men who guarded the coffin during its travel across the river and unloaded it. ${ }^{5}$

After all these interpretations regarding their nature, the question about their armless state remains unanswered. The arms are important for humans to perform tasks successfully, so losing these necessary appendices leads to retardation and a handicap for any person.

It is possible that these figures were seen as having finished their role and transformed into armless figures in a helpless state, stayed in a closed place, waiting for the resurrection after the body of the dead entered the netherworld. This is understood thanks to a passage from the Pyramid Texts: "This Unis will become truly functional, and his arms will not go off". 6

Regarding the five armless minor deities, their arms are intentionally missing as they appear with other normal minor deities with full bodies. Their role is known as "The helpers of the sun god Ra", his servants. They are supposed to be called by him to the hidden place to bring the secrets and the offerings every day. These secrets are in the boat of Ra, and the helpers live upon it, ${ }^{7}$ as the texts of this hour say.

"Lifting the mystery of this great god to the Hidden Chamber, day after day. They go forth with this great god to the sky". 8

The existence of armless deities among those with arms denotes the role that they might perform to serve the sun god. Their role is suspended, especially during the strengthless periods of the sun god. The weak period of the sun god started at the fifth hour of the night, which the twelve deities represent. The fifth hour of the night starts with the first armless deity, followed by the four others. From the names of the five minor deities, we conclude

\footnotetext{
${ }^{1}$ Settgast, Untersuchungen zu Altägyptischen Bestattungsdarstellungen, 55

${ }^{2} n s ̌ m t$ is the divine boat of Osiris in Abydos, Wb II, 339(15).

${ }^{3} \mathrm{CG}, 194 \mathrm{ff}$.

${ }^{4}$ The $M w w$ dancers exist in the funerary stage to greet the mummy when it reaches the place of burial, see: Altenmüller, H., "Muu”, in $L \ddot{A} I V$, 271-272; Junker, H., "Der Tanz der Mww und das Butische Begrabris im Alten Reich", in: MDAIK 9, Berlin, (1940), 1-39.

${ }^{5}$ Manniche, L., Lost Tombs A Study of Certain Eighteenth Dynasty Monuments in the Theban Necropolis, London and New York, (1988), 75.

${ }^{6}$ Allen, J.P., The Ancient Egyptian Pyramid Texts, Atlanta, (2005), 49 (spell 175).

${ }^{7}$ Hornung, E., Die Unterweltsbücher der Ägypter, (1997), 176.

${ }^{8}$ Leitz, L̈̈GG I, 342; Warburton, D., The Egyptian Amduat, The Book of the Hidden Chamber, Living Human Heritage Publications, Zurich, (2007).
} 
that there are three forms of the arm: a) A hidden arm (The second deity), b) A paralysed arm (The third deity), and c) An interior arm (The fifth deity).

Due to these different states, it is possible to suggest that the armless figures have their arms hidden inside their bodies. However, this is answered thanks to the Prehistoric examples of the figures with stumps replacing the arms. In addition, given that they are deities, we cannot conceive that their arms have been cut off, as they are considered guardians and not guilty of anything. As a result, the armless figures had hidden arms rather than inside their bodies, not represented, paralysing the hands.

\section{CONCLUSION}

The examples of the armless figures are directly connected to the burial scenes and the afterlife's sacred rituals. Human representations in ancient Egyptian material culture were associated with divine or magical rituals. Examples of armless anthropomorphic representations began with small scale figurines during Prehistoric times, then encompassed other ways of representation. The earliest figurines with stump arms replacing the arms dated to the Badari Period. Among figurines, anthropomorphic representations were rare, and their presence in Predynastic graves is thus considered a symbol of status.

Representing divine figures without arms was rare in ancient Egyptian art. In this paper, the author dealt with different armless figures:

a) Those who accompany the boats of the dead,

b) The four armless figures in the sacred land,

c) Divine figures of the afterlife.

The author suggested that those figures have a temporarily suspended role for some time. The absence of arms represents the weakness and the helpless state of the body.

Armless figures represent divine identities. They are figures of dead people or ancestors who may bless the deceased and his journey in the afterworld. They were a manifestation of a moment of transition of power and represented without arms to express a certain period of disability to do their duty until the resurrection.

Armless divine figures of the Amduat afterlife were represented at the night's second or the eleventh hour. Both hours can be interpreted as representing a transitional phase right after sunset and directly before sunrise. The armless god Neper is also a divine identity at a transitional state from germination to growth. In ancient Egypt, a horrific fate such as death was diluted in the minds of the Egyptians by thinking of it as a transition into a new state that rituals could ensure. It was embedded in their heritage since the time of formation of the state itself. The four armless figures inside a chapel were part of these rituals. They were described in the accompanying legend as: "Gods, keepers of the great gates", or in the Coffin Texts, "The doorkeepers of the district of silence". Being at the gates of the necropolis is in itself a transitional moment at one's sunset and a place of transition. This is supported by the colours of their body, yellow as the sun or blue as the night. Finally, I conclude that the representation of armless figures is influenced by the phases of the sun god, who has different phases during his journey from his powerful state to his weak one, which affected the manifestation of the armless figures. 


\section{BIBLIOGRAPHY}

1- Allen J.P., The Ancient Egyptian Pyramid Texts, Atlanta, (2005).

2- Altenmüller H., "Muu", L $\ddot{A} I V$, Wiesbaden (1979), 271-272.

3- Badawy A., A History of Egyptian Architecture, vol.I-III, Egypt 1954-1968.

4- Baikie J., Egyptian Antiquities in the Nile Valley, (1932).

5- Baines J., 'On the Status and Purpose of Ancient Egyptian Art', Cambridge Archaeological Journal 4.1, (1994),67-94.

6- Binder S., 'The Hereafter: Ancient Egyptian Beliefs with Special Reference to the Amduat', BACE 6 (1995).

7- Bommas M., 'Travels to the Beyond in Ancient Egypt', in Eurydice Georganteli and Martin Bommas (eds.) Sacred and Profane: Treasures of Ancient Egypt from the Myers Collection, Eton College and University of Birmingham, D Giles Limited, London, (2010).

8- Brunton G.\& Caton-Thompson G., 'The Badarian Civilization and Predynastic Remains near Badari', BSAE 46, London, (1928).

9- O'Connor D., Abydos, Egypt's First Pharaohs and the Cult of Osiris, (2009).

10- Ćwiek A., 'Relief Decoration in the Royal Funerary Complexes of the Old Kingdom, Studies in the development, Scene Content and Iconography', Warsaw University, (2003).

11- G. Davies N. de, The Tomb of Antefoker of Sesostris I and of his Wife Senet (no.60), The Theban Tomb Series II, London, (1920).

12-................. The Tombs of Menkheperrasonb, Amenmose and Another (Nos 86,112,42, 226), The Theban Tomb Series V, (1933).

13-.................., The Tomb of Puyemre at Thebes, vol.I-II, New York, (1923).

14-..................., The Tomb of Rekhmire at Thebes, PMMA XI, (1973).

15- Davies N.M., "An Unusual Depiction of Ramesside Funerary Rites”, JEA 32 , (1946), 69-70.

16- Demarée R.J., The 3h iqr $n$ R3 Stelae, On Ancestor Worship in Ancient Egypt, (1983).

17- Diamond K.A., Transporting the Deceased to Eternity: The Ancient Egyptian Term h3i, BAR International Series 2179, (2010).

18- Fathy N., 'Hkkr (Kheker) Frieze in Ancient Egypt', JGUAA 2, (2017), 132-158.

19- Faulkner R.O., The Ancient Egyptian Coffin Texts, I-III, UK, (1973-1978).

20-FCD= R.O.Faulkner, A Concise Dictionary of Middle Egyptian, Oxford, (1991).

21- Gaballa G.A., Narrative in Egyptian Art, Philipp von Zabern, Mainz am Rhein (1976),77.

22- Gardiner A., Egyptian Grammar, Being an Introduction to the Study of Hieroglyphs, Oxford, (1957).

23- Gauthier H., Dictionnaire des Noms Géographiques Contenus dans les Textes Hiéroglyphiques, vol. III, Cairo, 1925.

24- Goyon J.C., Rituels Funéraires de l'Ancienne Égypte, Paris, (1972).

25- Griffith T., The Tomb of Paheri at el Kab, The Egypt Exploration Fund 11, London, (1894).

26- Guilhou N., 'Génies Funéraires: Croquemitaines ou Anges Gardiens? Étude sur les Fouets, Balais, Palmes et Épis en Guise de Couteaux", Encyclopédie Religieuse de l'Univers Végétal. Croyances Phytoreligieuses de l'Égypte Ancienne I, (1999), 356-417.

27- Harrington N., Living with the Dead, Ancestor Worship and Mortuary Ritual in Ancient Egypt, (2013).

28- Hendrickx S., "Iconography of the Predynastic and Early Dynastic Periods". In Emily Teeter (ed.) Before the Pyramids: The Origins of Egyptian Civilization, OIP 33, Chicago (2011), pp. 75-81, p.76.

29- Hornblower G.D., Predynastic Women and their Successors, IN: JEA 15 (1929), 29-47. 30- Hornung E., 'Amduat', in $L \ddot{A} I$, Wiesbaden, (1975), 184-187. 

Die Unterweltsbücher der Ägypter, (1997).

32-............, The Ancient Egyptian Books of the Afterlife, London: Cornell University Press (1999).

33- Junker H., "Der Tanz der Mww und das Butische Begrabris im Alten Reich", IN: MDAIK 9, Berlin, (1940), 1-39.

34- Kaiser W., “Zu den $¥$ ○林 der Alteren Bilddarstellungen und der Bedeutung von rpwt, IN: MDAIK 39 (1983), 274-296.

35- Kanawati N.\& Woods A., Artists in the Old Kingdom; Techniques and Achievements, Cairo, (2009).

36-..... Beni Hassan, Art and Daily life in an Egyptian Province, Cairo 2010).

37- Kanawati N., Beni Hassan, vol.I, The Tomb of Khnumhotep II, Australian Centre for Archaeology Reports 36, (2014).

38- Lange H.O. \& Schäfer H., Catalogue Général des Antiquités Égyptiennes du Musée du Caire No.20001-20780, Grab-und Denksteine des Mittleren Reichs, Theil II, Berlin, (1908). 39- Leitz Ch. (ed.), Lexikon der Ägyptischen Götter und Götterbezeichnungen, I-VII, Louvain (2002).

40- IIona R., Abydos. The Sacred Land at the Western Horizon, British Museum Publications on Egypt and Sudan 8, (2019).

41- Lucarelli R., The Guardian-Demons of the Book of the Dead, British Museum Studies in Ancient Egypt and Sudan 15, London, (2010), 85-102.

42- Mackay E., "Kheker friezes", Ancient Egypt I, London and New York, (1920).

43- Manniche L., Lost Tombs, A Study of Certain Eighteenth Dynasty Monuments in the Theban Necropolis, London and New York, (1988).

44- Newberry P., Beni Hassan, Part I-II, Archaeological Survey of Egypt Memoir 1-2, London (1893).

45- Ordynat R., The Female Form: Examining the Function of Predynastic Female Figurines from the Badarian to the Late Naqada II Periods, BA Thesis, Monash University, Australia, (2013).

46-..........., 'Predynastic Female Figurines: A Reappraisal of the Ma'mariya Corpus', in Jessica Cox, Caleb R. Hamilton, Katherine R.L. McLardy, Amy J. Pettman and David Stewart (eds.), "Ancient Culture at Monash University, Proceedings of a Conference Held Between 18-20 October 2013 on Approaches to Studying the Ancient Past, British Archaeological Reports (BAR) International Series 2764, Archaeopress, Oxford, (2015), 119.

47-.........., Egyptian Predynastic Anthropomorphic Objects: A Study of their Function and Significance in Predynastic Burial Customs. Archaeopress Access Archaeology, Oxford, (2018).

48- Patch D.C. (ed.), Dawn of Egyptian Art, Metropolitan Museum of Art, New York, (2012). 49- Payne J.C., 'Forged Decoration on Predynastic Pots', in JEA 63, London, (1977), 5-12. 50-PM= Porter B.\& Moss R., Topographical bibliography of Ancient Egyptian Hieroglyphic Texts, Reliefs and Paintings (The Theban Necropolis), vol.I, Oxford, 1994).

51- Petrie W.M.F., Prehistoric Egypt, London, (1920).

52-.............., Egyptian Decorative Art, London, (1895).

53-.............., Ancient Egypt, British School of Archaeology, (1914-1942).

54- Piankoff A.\& Rambova N., The Tomb of Ramesses VI, NJ (Princeton University Press/Bollingen Series XL.1) (1954).

55- Robins G., Proportion Style in Ancient Egyptian Art, Texas, (1994).

56- Settgast J., 'Untersuchungen zu Altägyptischen Bestattungsdarstellungen', in ADAIK 3, New York (1963).

- 73 - DOI: $10.21608 /$ shedet.2021.207778 
57- Shaw I. \& Nicholson P., The British Museum Dictionary of Ancient Egypt, Cairo, (2002), 150

58- Smith W.S., A History of Egyptian Sculpture and Paintings in the Old Kingdom, $2^{\text {nd }}$ ed., Boston, (1949).

59- Stevens C.J., The Oxford Dictionary of Architecture, (2016).

60- Vanhulle D., Boat Symbolism in Predynastic and Early Dynastic Egypt: An EthnoArchaeological Approach. JAEIN 17, (2018), 173-187.

61- Warburton D., The Egyptian Amduat, The Book of the Hidden Chamber, Living Human Heritage Publications, Zurich, (2007).

62- Weeks K.R., The Anatomical Knowledge of Ancient Egyptians and the Representation of Human Figure in Egyptian Art, PhD diss., Yale University, (1970).

63- Wunn, I.\& Grojnowski D., 'The Origin of Religion in the Evolution of Humans', in Ina Wunn and Davina Grojnowski (eds.), Religious Speciation: How Religions Evolve, New Approaches to the Scientific Study of Religion, NASR 6 (2019), 223-241.

64-Wb = Erman, A.\& Grapow, H., Wörterbuch der Ägyptischen Sprache I-V, Leipzig 19261931.

65- El-Yahky, F., 'Remarks on the Armless Human Figures Represented on Gerzean Boats', in JSSEA XI-No.2 (1981), 77ff. 